\title{
Semi-pelagic Longline and Trammel Net Elasmobranch Catches in Southern Portugal: Catch Composition, Catch Rates and Discards
}

\author{
Rui Coelho, Karim Erzini, Luís Bentes, Carla Correia, Pedro G. Lino, \\ Pedro Monteiro, Joaquim Ribeiro, and Jorge M. S. Gonçalves \\ Universidade do Algarve, CCMAR/FCMA, Campus de Gambelas, 8000 Faro, Portugal \\ Coelho, R., K. Erzini, L. Bentes, C. Correia, P. G. Lino, P. Monteiro, J. Ribeiro, and J. M. S. Gon- \\ çalves. 2005. Semi-pelagic Longline and Trammel Net Elasmobranch Catches in Southern Portugal: \\ Catch Composition, Catch Rates and Discards. J. Northw. Atl. Fish. Sci., 35: 531-537. doi:10.2960/ \\ J.v35.m482
}

\begin{abstract}
In Portugal, elasmobranch landings have decreased substantially in recent years. In this work, elasmobranch catches in semi-pelagic longlines (1997 and 1998) were compared with those in trammel nets (2000) in the Algarve, southern Portugal areas. In the semi-pelagic longline fishery, 7 elasmobranch species represented 33.4\% (2 185 specimens) of the total fish catches. Among the elasmobranch species, the most abundant were Galeus melastomus (63.3\%), Etmopterus pusillus (21.7\%) and Scyliorhinus canicula $(14.2 \%)$. Most of these elasmobranchs were discarded (68.3\% in total). In the trammel net fishery, 16 different elasmobranch species represented $4.3 \%$ (597 specimens) of total fish catches and the most important species were Raja undulata (43.6\%) and $S$. canicula $(10.2 \%)$. The majority of the elasmobranchs caught in trammel nets had commercial value, and only $5.4 \%$ were discarded. In both fisheries, intra-specific catch rates varied with depth. Length-frequency distributions for the only species with relatively high catches in both fisheries, $S$. canicula, showed that, in general, trammel nets catch larger specimens and in a narrower length range than do longlines.
\end{abstract}

Key words: catch composition, catch rate, discard, longline, Portugal, trammel net

\section{Introduction}

Elasmobranch fishes have life strategies that make them especially vulnerable to overexploitation (Pratt and Casey, 1990). Worldwide, the problem of elasmobranch overexploitation has been well documented for targeted fisheries (Hurley, 1998; Stevens et al., 2000), for the high levels of by-catch (Buencuerpo et al., 1998; Mckinnell and Seki, 1998), and for other fishing activities, such as recreational fishing (Francis, 1998).

Elasmobranch fishes are a very important component of the by-catch of the artisanal fisheries in Portugal (Erzini et al., 2000; Erzini et al., 2001), but no management program has been established yet. In recent years, catches decreased $46.3 \%$ in the Algarve, southern Portugal (from 888.1 tons in 1988 to 477.0 tons in 2000 ) and $30.1 \%$ at a national level (from 5634.4 tons in 1997 to 3938.6 tons in 2000) (DGPA, 2000) (Fig. 1). In some cases, these reductions have been drastic and might even indicate that these species are at high risk. Such is the case of the gulper shark (Centrophorus granulosus) where there was a catch reduction of $92.3 \%$ at a national level and $80.4 \%$ in the Algarve, or the smooth hounds (Mustelus spp.) that registered reductions of $79.4 \%$ at a national level and $54.2 \%$ in the Algarve. The rays and skates (Raja spp.) have also suffered great reductions, $43.8 \%$ at a national level and $48.7 \%$ in the Algarve.
Here we describe and compare elasmobranch catches in two different types of artisanal fisheries using trammel sets and semi-pelagic longlines in the Algarve, southern Portugal. Catch composition and catch rates were compared by descriptive statistics and discards were analyzed for both fisheries.

\section{Material and Methods}

Fishing trials with the semi-pelagic longlines were carried out from March 1997 to August 1998. A total of 20 fishing trials (10 per year) were carried out by a commercial longline vessel that usually operates in these waters, and the fishing took place on traditional fishing grounds in the Algarve, at depths from 210 to $550 \mathrm{~m}$ (Fig. 2). The semi-pelagic longline used consisted of a $1.60 \mathrm{~mm}$ diameter monofilament main line with 0.90 $\mathrm{mm}$ diameter monofilament gangions of approximately $1.2 \mathrm{~m}$ attached without swivels, directly to the mainline, at intervals of approximately $1.8 \mathrm{~m}$. The longline was lifted off the seabed by glass buoys ("bolas") at intervals of 40 hooks, and weighted with small rocks ("pedras") in between. The longlines were stored in plastic tubs, each containing 120 hooks. Four hook sizes (numbers Siapal $10,9,7$ and 5. The mean number of tubs used per set was 44, with 11 tubs (1 320 hooks) of each hook size. Frozen sardines were thawed during transit to the fishing grounds, 
cut in half, and used to bait the longline. The total length of the longline was between 10 and $15 \mathrm{~km}$ and typically, the fishing trips were $17-21 \mathrm{hr}$. All the hooks were registered for position and presence or absence of bait and

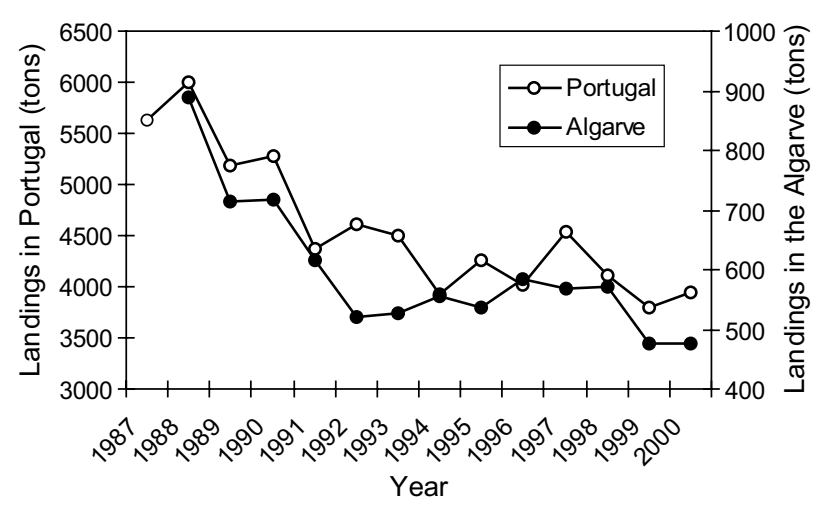

Fig. 1. Landings of elasmobranchs captured in both Portuguese waters (from 1987 to 2000) and in the Algarve, southern Portugal (from 1988 to 2000). All values are in tons ( $\mathrm{t}$ ). (DGPA, 2000). catches. All the catches were quantified by species and total length (TL, $\mathrm{mm}$ ) was recorded for the target species, the European hake (Merluccius merluccius), and the most important by-catch elasmobranch species.

Experimental fishing trials with the trammel nets were carried out in 2000, from January to November, on a seasonal basis with ten fishing trials per season. Fishing was carried out by a commercial fishing vessel and took place on traditional fishing grounds in the Algarve. Fishing depths varied from 10 to $90 \mathrm{~m}$ (Fig. 2). The experimental trammel nets consisted of two larger mesh outer panels (600 and $800 \mathrm{~mm}$ stretched mesh) and three smaller mesh inner panels $(100,120,140 \mathrm{~mm}$ stretched mesh). Thus, experimental nets consisted of six different combinations and each combination comprised five nets with equal mesh size for each panel. Overall five groups of these six combinations, each with five nets were used, giving a total of 150 nets. The six distinct combinations were joined together by a footrope, leaving a 2-m gap between them. A total length of $8900 \mathrm{~m}$ of trammel nets, consisting of 2500,3000 and $3400 \mathrm{~m}$, each inner mesh

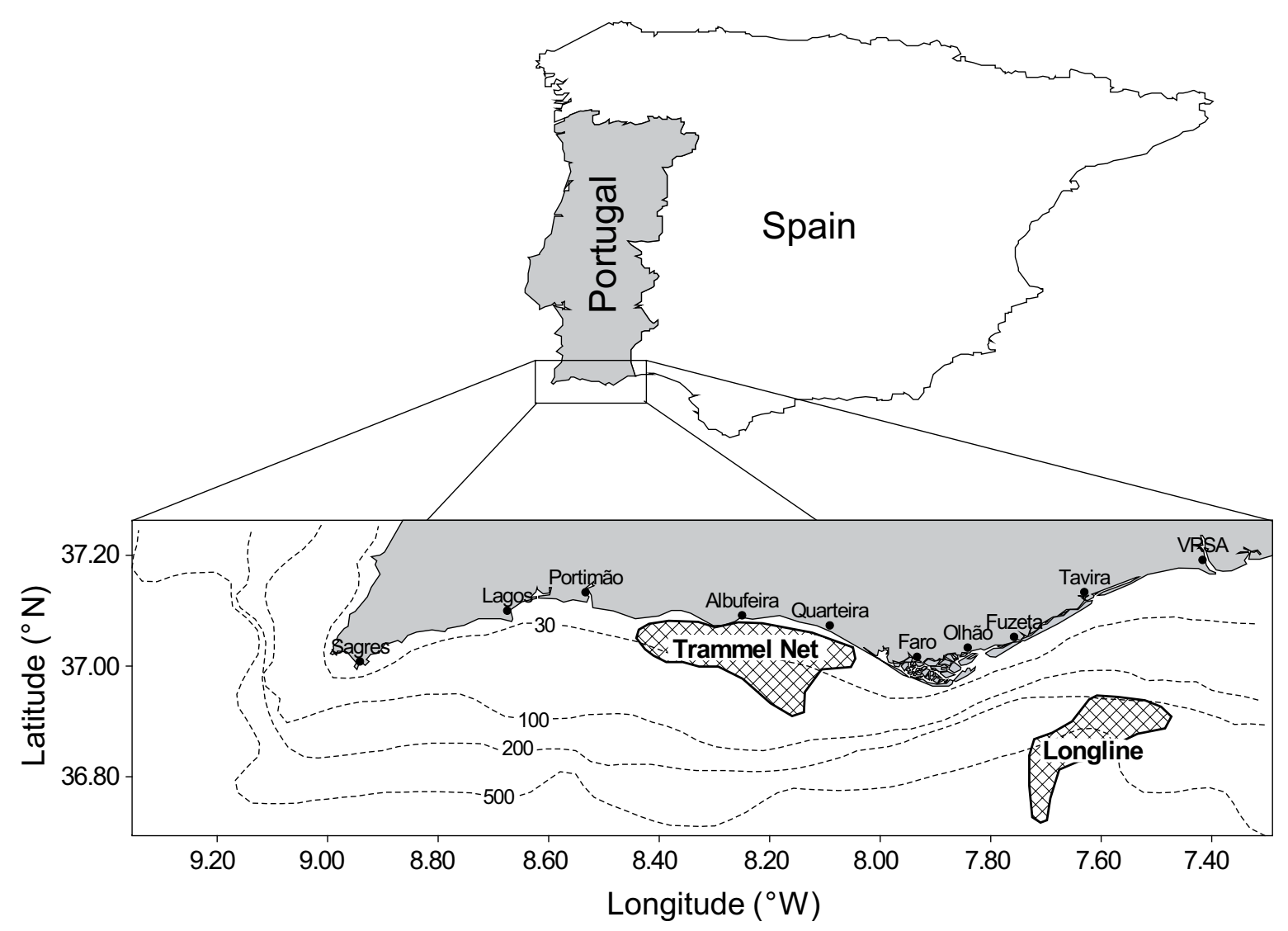

Fig.2. Map of the Algarve coastline with the location of the fishing grounds of the trammel nets and the longlines used in this study. 
size 100, 120 and $140 \mathrm{~mm}$, respectively, were used. Normal fishing practices were followed, with the setting of the gear during the afternoon or evening before sunset and hauling after sunrise. All captured fishes were separated, identified and measured as they came aboard.

Catches from both fisheries were classified according to value and fate of the specimens as commercial, discard or self-consumption. Catch rates were calculated for each species in number of fish per $1000 \mathrm{~m}$ for the trammel nets and number of fish per 1000 hooks for the semi-pelagic longline. Additionally, catch rates were calculated for each fishing gear and for each species, according to depth. Length-frequency distributions for the only species that had relatively high catches in both fisheries, the small-spotted catshark (Scyliorhinus canicula), were constructed by gear and compared using the Kolmogorov-Smirnov test.

\section{Results}

In the semi-pelagic longline fishery, seven different elasmobranch species were captured, representing 33.4\% of the total catch. All specimens were identified to species, except for four rays identified as Raja sp. The most abundant species were the blackmouth catshark (Galeus melastomus), (comprising $63.3 \%$ of the elamobranchs, 1383 specimens), followed by the smooth lanternshark (Etmopterus pusillus) $(21.7 \%, 474$ specimens), and $S$. canicula (14.2\%, 310 specimens). These three species together accounted for more than $99 \%$ of the elasmobranch catch in this fishery (Table 1).

In the trammel net fishery, elasmobranch catches accounted for $4.3 \%$ (597 specimens) of the total catch. A total of 16 species were caught. All fishes were identified, except for one that could only be identified as Raja sp. The most abundant elasmobranch species were the undulate ray (Raja undulata) (43.6\%, 260 specimens), and $S$. canicula $(10.2 \%, 61$ specimens) (Table 1$)$.

In the trammel nets, most of the elasmobranchs were either landed for sale or consumed by the fishermen themselves. Discards were low, accounting for only $5.4 \%$ of the elasmobranch catch. On the other hand, in the semi-pelagic longline there was a much higher level

TABLE 1. Catches by number with the respective length characteristics of elasmobranchs captured by each fishing gear.

\begin{tabular}{|c|c|c|c|c|c|c|c|}
\hline \multirow[b]{2}{*}{ Gear } & \multirow[b]{2}{*}{ Species } & \multirow[b]{2}{*}{$\mathrm{n}$} & \multicolumn{5}{|c|}{ Total length characteristics (mm) } \\
\hline & & & Mean & SD & Min & Max & $\overline{\text { Range }}$ \\
\hline \multirow{7}{*}{$\begin{array}{l}\text { Semi- } \\
\text { pelagic } \\
\text { longline }\end{array}$} & Galeus melastomus & 1383 & 489 & 115 & 185 & 899 & 714 \\
\hline & Etmopterus pusillus & 474 & 340 & 51 & 203 & 510 & 307 \\
\hline & Scyliorhinus canicula & 310 & 413 & 83 & 210 & 595 & 385 \\
\hline & Prionace glauca & 6 & 773 & 169 & 605 & 1030 & 425 \\
\hline & Chimaera monstrosa & 4 & 880 & 109 & 788 & 997 & 217 \\
\hline & Mustelus mustelus & 2 & 1430 & - & 1430 & 1430 & - \\
\hline & Raja clavata & 2 & 691 & 37 & 665 & 717 & 52 \\
\hline \multirow{16}{*}{$\begin{array}{l}\text { Trammel } \\
\text { net }\end{array}$} & Raja undulata & 260 & 658 & 119 & 365 & 845 & 480 \\
\hline & Scyliorhinus canicula & 61 & 523 & 43 & 419 & 740 & 321 \\
\hline & Raja clavata & 55 & 662 & 129 & 395 & 865 & 470 \\
\hline & Raja asterias & 53 & 614 & 106 & 393 & 930 & 537 \\
\hline & Raja brachyuran & 50 & 586 & 164 & 305 & 935 & 630 \\
\hline & Torpedo marmorata & 33 & 405 & 104 & 175 & 610 & 435 \\
\hline & Torpedo torpedo & 33 & 351 & 67 & 210 & 545 & 335 \\
\hline & Raja miraletus & 31 & 436 & 121 & 197 & 565 & 368 \\
\hline & Pteromylaeus bovines & 7 & 787 & 80 & 640 & 910 & 270 \\
\hline & Prionace glauca & 3 & 1067 & 55 & 1010 & 1120 & 110 \\
\hline & Raja oxyrinchus & 3 & 1235 & 445 & 920 & 1550 & 630 \\
\hline & Isurus oxyrinchus & 2 & 883 & 38 & 856 & 910 & 54 \\
\hline & Torpedo nobiliana & 2 & 335 & 11 & 327 & 343 & 16 \\
\hline & Galeorhinus galeus & 1 & 1375 & - & 1375 & 1375 & - \\
\hline & Myliobatis aquila & 1 & 540 & - & 540 & 540 & - \\
\hline & Raja naevus & 1 & 655 & - & 655 & 655 & - \\
\hline
\end{tabular}


of discarding of elasmobranchs, accounting for $68.3 \%$ of the catch (Table 2). Although measurements of catch rates with the different fishing gears are not directly comparable, catch rates are generally higher for the longline. This is particularly evident for one species ( $S$. canicula), which is the only species where catches occurred in large numbers in both fishing gears (Table 3 ).

In both fisheries, intra-specific catch rates varied with depth. In the trammel net fishery, the two most important species by number had different catch rate patterns. For $R$. undulata, the highest catch rates were in the shallower depths with a progressive decrease in catch rate with depth, whereas for $S$. canicula, the opposite pattern was observed, with the highest catch rates in deeper waters. In the case of the semi-pelagic longline, the three numerically most important species had similar patterns of variation with depth. Catch rates peaked in the two depth ranges 200-300 $\mathrm{m}$ and 500-560 $\mathrm{m}$ (Fig. 3).

Comparison of the length-frequency distributions for $S$. canicula shows that, in general, trammel nets caught larger specimens and in a narrower length range than longlines. On the other hand, longlines caught smaller individuals in a wider range of lengths (Fig. 4). The Kolmogorov-Smirnov test showed that those distributions were significantly different $(\mathrm{P}<0.001)$.

\section{Discussion}

Analysis of the catch compositions and catch rates of both fishing gears showed that catches of sharks with the

TABLE 2. Fate of elasmobranchs captured by each fishing gear. For each species, the numbers of specimens landed or discarded are given, followed by the respective percentage in brackets. The commercial category includes fish that were sold at auction or consumed by the fishermen.

\begin{tabular}{|c|c|c|c|c|}
\hline \multirow[b]{2}{*}{ Gear } & \multirow[b]{2}{*}{ Species } & \multicolumn{3}{|c|}{ Fate } \\
\hline & & $\mathrm{n}$ & Commercial & Discard \\
\hline \multirow{8}{*}{$\begin{array}{l}\text { Semi- } \\
\text { pelagic } \\
\text { longline }\end{array}$} & Galeus melastomus & 1383 & $646(46.7 \%)$ & $737(53.3 \%)$ \\
\hline & Etmopterus pusillus & 474 & - & $474(100.0 \%)$ \\
\hline & Scyliorhinus canicula & 310 & $32(10.3 \%)$ & $278(89.7 \%)$ \\
\hline & Prionace glauca & 6 & $6(100.0 \%)$ & - \\
\hline & Raja sp. & 4 & $4(100.0 \%)$ & - \\
\hline & Chimaera monstrosa & 4 & - & $4(100.0 \%)$ \\
\hline & Mustelus mustelus & 2 & $2(100.0 \%)$ & - \\
\hline & Raja clavata & 2 & $2(100.0 \%)$ & - \\
\hline \multicolumn{2}{|l|}{ Total } & 2185 & $692(31.7 \%)$ & $1493(68.3 \%)$ \\
\hline \multirow{17}{*}{$\begin{array}{l}\text { Trammel } \\
\text { net }\end{array}$} & Raja undulata & 260 & $254(97.7 \%)$ & $6(2.3 \%)$ \\
\hline & Scyliorhinus canicula & 61 & $59(96.7 \%)$ & $2(3.3 \%)$ \\
\hline & Raja clavata & 55 & $50(90.9 \%)$ & $5(9.1 \%)$ \\
\hline & Raja asterias & 53 & $52(98.1 \%)$ & $1(1.9 \%)$ \\
\hline & Raja brachyuran & 50 & $47(94.0 \%)$ & $3(6.0 \%)$ \\
\hline & Torpedo marmorata & 33 & $32(97.0 \%)$ & $1(3.0 \%)$ \\
\hline & Torpedo torpedo & 33 & $32(97.0 \%)$ & $1(3.0 \%)$ \\
\hline & Raja miraletus & 31 & $27(87.1 \%)$ & $4(12.9 \%)$ \\
\hline & Pteromylaeus bovines & 7 & - & $7(100.0 \%)$ \\
\hline & Prionace glauca & 3 & $3(100.0 \%)$ & - \\
\hline & Raja oxyrinchus & 3 & $3(100.0 \%)$ & - \\
\hline & Isurus oxyrinchus & 2 & $2(100.0 \%)$ & - \\
\hline & Torpedo nobiliana & 2 & $2(100.0 \%)$ & - \\
\hline & Galeorhinus galeus & 1 & $1(100.0 \%)$ & - \\
\hline & Myliobatis aquila & 1 & - & $1(100.0 \%)$ \\
\hline & Raja naevus & 1 & $1(100.0 \%)$ & - \\
\hline & Raja sp. & 1 & - & $1(100.0 \%)$ \\
\hline Total & & 597 & $565(94.6 \%)$ & $32(5.4 \%)$ \\
\hline
\end{tabular}


TABLE 3. Mean catch rate, with standard deviation (SD), for each of the most abundant species caught by semi-pelagic longline and trammel net.

\begin{tabular}{|c|c|c|c|c|}
\hline \multirow[b]{2}{*}{ Species } & \multicolumn{2}{|c|}{ Catch rate (No. per 1000 hooks) } & \multicolumn{2}{|c|}{ Catch rate (No. per $1000 \mathrm{~m}$ ) } \\
\hline & Mean & $\mathrm{SD}$ & Mean & $\mathrm{SD}$ \\
\hline Etmopterus pusillus & 2.23 & 2.72 & - & - \\
\hline Galeus melastomus & 5.09 & 6.21 & - & - \\
\hline Raja asterias & - & - & 0.15 & 0.20 \\
\hline Raja brachyura & - & - & 0.14 & 0.69 \\
\hline Raja clavata & - & - & 0.15 & 0.49 \\
\hline Raja miraletus & - & - & 0.08 & 0.26 \\
\hline Raja undulata & - & - & 0.72 & 0.91 \\
\hline Scyliorhinus canicula & 2.17 & 3.29 & 0.17 & 0.53 \\
\hline Torpedo marmorata & - & - & 0.09 & 0.12 \\
\hline Torpedo torpedo & - & - & 0.09 & 0.16 \\
\hline
\end{tabular}
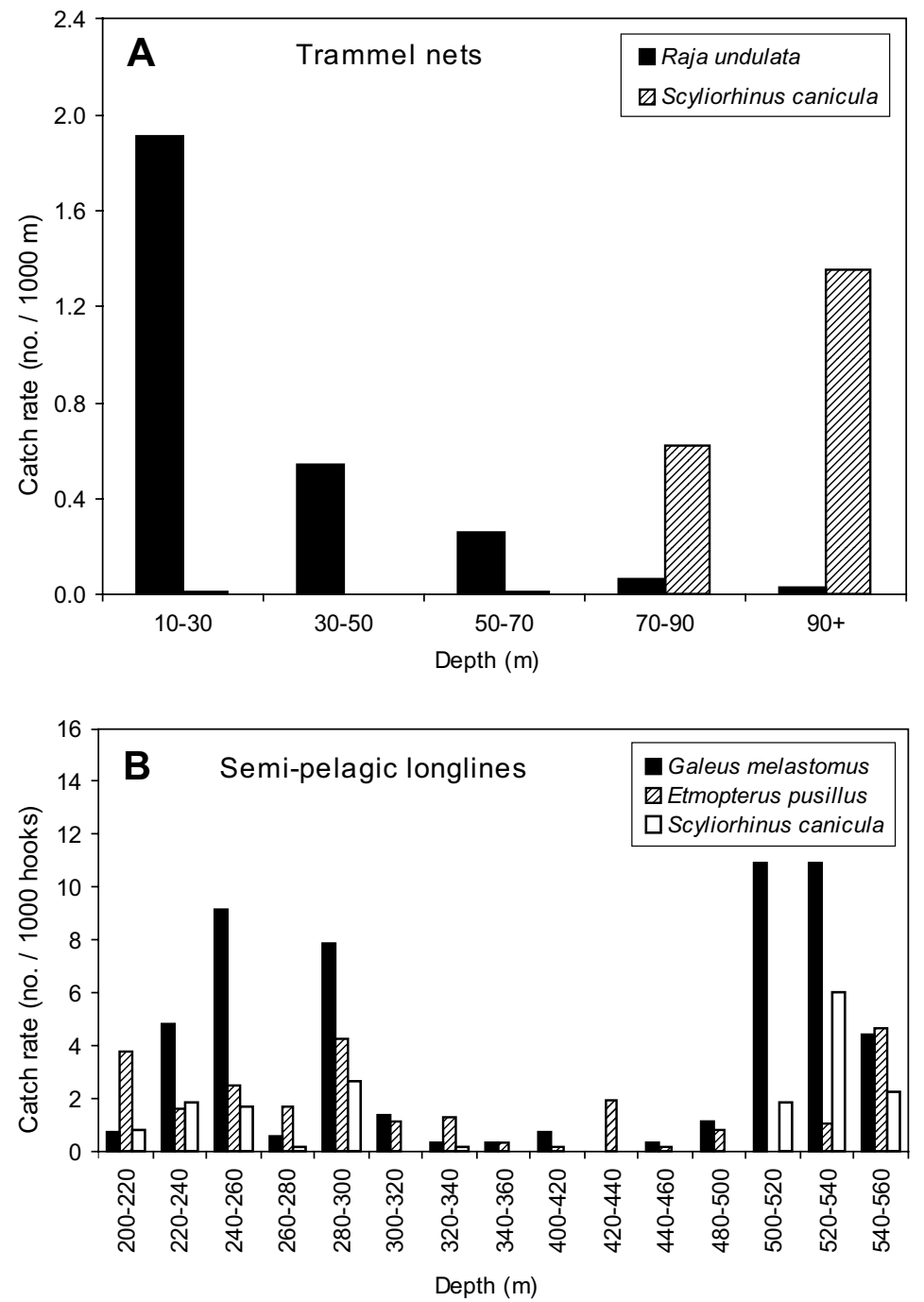

Fig. 3. Catch rates with depth for the most important elasmobranch species in trammel nets (A) and semi-pelagic longlines (B). Note that there are some missing depth ranges, namely, 360-380, 380-400 and 460-480 $\mathrm{m}$ where no fishing trials occurred. 


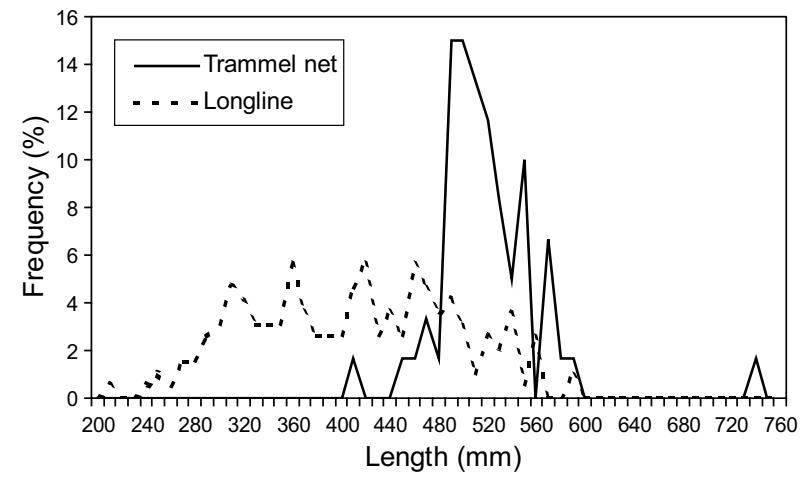

Fig. 4. Length-frequency distributions of Scyliorhinus canicula captured by trammel nets and semi-pelagic longlines.

semi-pelagic longlines are very high. The fact that most of these catches consist of deep-water sharks, occurring generally deeper than $400 \mathrm{~m}$ (Bergstad et al., 2003), which are especially sensitive to exploitation, may be cause for concern. On the other hand, trammel nets capture mainly rays ( $R$. undulata) that occur mostly in waters on the continental shelf less than $200 \mathrm{~m}$ depth (Stehmann and Burkel, 1984) and probably have higher productivity than the deep-water sharks. Moreover, the rays are more likely than the deep-water sharks to be landed for sale.

The official fisheries statistics are based on fish sold at auction and are likely to be misleading for deep-water sharks. Most of these animals are discarded at the sea, either dead or severely injured, and are therefore not accounted for in the statistics. The deep-water species are characterised by very slow growth rates and low fecundities (Clarke et al., 2001; Guallart and Vicent, 2001), making them particularly sensitive to over exploitation. None of the captured species is listed in the IUCN Red List for endangered species, and no management programs exist in Portugal.

Although semi-pelagic longline catch rates are higher than trammel net catch rates, these results are not directly comparable and can only be regarded as informative data. To begin with, the catch rates are expressed in different units: number per 1000 hooks for longline and number per $1000 \mathrm{~m}$ for trammel net. Secondly, these fishing gears operate in different types of habitats (different depths) where the relative abundances of the species may be different. Also, longlines with baited hooks attract fish from considerable distances (Bjordal and Løkkeborg, 1996), whereas trammel nets depend on the normal movements of fish. Finally, sampling took place in different years, which can also contribute to the observed differences. Nevertheless, these values can be used as baseline data and they do give an idea of fishing pressure on elasmobranchs with these fishing gears.

The analysis of the length-frequency distributions of $S$. canicula gives a very interesting result; it shows that trammel nets mainly capture larger specimens than do the semi-pelagic longlines. Considering trammel nets operate in much shallower waters than the semi-pelagic longlines, these results might contradict the traditional generalization that larger specimens occur at greater depths. However, it is important to note that sampling took place with different fishing gears, leading to the possibility that the differences in length distributions are a result of gear selectivity rather than depth. If this is the case, we can conclude that small S. canicula specimens may occur in shallow waters, but are not fully selected by the trammel nets.

\section{References}

BERGSTAD, O. A., J. D. M. GORDON, and P. LARGE. 2003. Is time running out for deepsea fish? ICES electronic article. http://www.ices.dk/marineworld/deepseafish.asp. Accessed in September 2003.

BJORDAL, Å., and S. LØKKEBORG. 1996. Longlining. Fishing News Books, Oxford.

BUENCUERPO, V., S. RÍOS, and J. MORÓN. 1998. Pelagic sharks associated with the swordfish, Xiphias gladius, fishery in the eastern North Atlantic Ocean and the Strait of Gibraltar. Fish. Bull., 96: 667-685.

CLARKE, M. W., P. L. CONNOLLY, AND J. J. BRACKEN. 2001. Aspects of reproduction of the deep-water sharks Centroscymnus coelolepis and Centrophorus squamosus from west of Ireland and Scotland. J. Mar. Biol. Ass. U.K., 81: 1019-1029.

DGPA. 2000. Recursos da pesca. Série Estatística 1999. Direç̧ão-Geral das Pescas e Aquicultura, vol. 13 A-B, $170 \mathrm{p}$.

ERZINI, K., E. PUENTE, L. ARREGUI, L. BENTES, M. CASTRO, J. M. S. GONÇALVES, P. G. LINO, J. RIBEIRO, J. P. SANTIAGO, and F. SOUSA. 2000. Hake semi-pelagic longline selectivity and evaluation of selectivity models for hook and line gear. Final report. Commission of the European Communities, DG XIV/C/1, Ref. 96/062, 190 p.

ERZINI, K., K. STERGIOU, E. PUENTE, and J.A. HERNANDO. 2001. Trammel net selectivity studies in the Algarve (Southern Portugal), Gulf of Cadiz (Spain), Basque Country (Spain) and Cyclades (Greece). Final report. Commission of the European Communities, DG XIV/C/1, Ref. 98/014, $435 \mathrm{p}$.

FRANCIS, M. P. 1998. New Zealand shark fisheries: development, size and management. Mar. Freshw. Res., 49: 579-591.

GUALLART, J., and J. J. VICENT. 2001. Changes in composition during embryo development of the gulper shark, Centrophorus granulosus (Elasmobranchii, Centrophoridae): An assessment of maternal-embryonic nutritional 
relationships. Environ. Biol. Fishes, 61: 135-150.

HURLEY, P.C.F. 1998. A review of the fishery for pelagic sharks in Atlantic Canada. Fish. Res. 39: 107-113.

MCKINNELL, S., and M. P. SEKI. 1998. Shark by-catch in the Japanese high seas squid driftnet fishery in the North Pacific Ocean. Fish. Res., 39: 127-138.

PRATT, H. L., and J. G. CASEY. 1990. Shark reproductive strategies as a limiting factor in directed fisheries, with a review of Holden's method of estimating growth-parameters. In: Elasmobranchs as living resources: advances in the biology, ecology, systematics, and the status of the fisheries.
H. L. Pratt, S. H. Gruber, T. Taniuchi (eds.). U.S. Dep. Commer., NOAA Tech. Rep., No. NMFS 90: 97-109.

STEHMANN, M., and D. L. BURKEL. 1984. Rajidae. In: Fishes of the North-eastern Atlantic and Mediterranean (Vol. I). P. J. P. Whitehead, M. L. Bauchot, J. C. Hureau, J. Nielsem, and E. Tortonese (eds.). United Nations Educational, Scientific and Cultural Organization, pp. 163-196.

STEVENS, J. D., R. BONFIL, N. K. DULVY, and P. A. WALKER. 2000. The effects of fishing on sharks, rays, and chimaeras (chondrichthyans), and the implications for marine ecosystems. ICES J. Mar. Sci., 57: 476-494. 
